\title{
PARTICULARITIES OF HOLLOW-CORE BRIQUETTES OBTAINED OUT OF SPRUCE AND OAK WOODEN WASTE
}

\author{
Cosmin Spirchez ${ }^{1}$, Aurel Lunguleasa ${ }^{2, \bullet}$, Madalina Matei ${ }^{3}$
}

\begin{abstract}
Wooden hollow-core briquettes made of wooden waste represent an important category of woodbased combustible materials used in heating chambers. This paper aims to determine some of the characteristics of these briquettes made of spruce and oak waste. The comparison to the classic types of briquettes is made in order to identify the advantages and disadvantages of such briquettes. The main characteristics of these briquettes are presented, starting from size, density, abrasion, compression and ending with the inferior and superior calorific values, calorific density and ash content. The obtained results show that there are few differences between their characteristics and those of the classic ones. These differences depend on the pressing method and equipment, in comparison to other briquettes without a hollow core. Apart from the characteristics and the nature of the material being used, the hollow-core briquettes remain renewable combustible materials increasingly used in combustion (for heating purposes or in order to cook food or for heating in rural households or as substitutes for charcoal or cogenerate in various industrial fields). Given their economical character, there is complete suitability of these briquettes for cooking and heating.
\end{abstract} waste.

Keywords: Biomass, calorific value, Picea abies, Quercus ruber, renewable combustible, wooden

\section{INTRODUCTION}

Lignocellulosic waste represents a category of wooden biomass which is increasingly available in natural environments (Boutin et al. 2007). This starts from the wood exploitation in forests (Lundborg 1998), and ends with the chemical processing of wood and of the waste resulted from demolitions. A significant part of this biomass can be found in wood processing plants as log ends, and- other types of waste resulted from the processing of timber, chips, dust, etc. A considerable amount also results from the maintenance of parks and trees from the large human settlements. If there were no care for its constant use, waste would undoubtedly transform into garbage, which would pollute the environment (Ciubotă-Roşie et al. 2008, Gavrilescu 2008, Jehlickova and Morris 2007). Proper management of any wooden waste contributes to the reduction of global warming (Dhillon and von Wuelhlisch 2013, Kim and Dale 2003, Lakó et al. 2008, Thomas and Malczewski 2007), by keeping forests live. The dimensional variety of these kinds of wastes makes their combustion into the regular heating chambers almost impossible in their original state, as all waste needs to be chopped and only afterwards transformed into briquettes and pellets. Wooden briquettes may vary in terms of size (diameters from 12 $\mathrm{mm}$ up to $120 \mathrm{~mm}$ ) more widely than the wooden pellets (with diameters of 8-12 $\mathrm{mm}$ ), as provisioned in the European standards. Moreover, in case of briquettes, the raw material can be dimensionally more varied, and more so as regards the combination of wooden species.

\footnotetext{
${ }^{1}$ Assistent professor at Transilvania University of Brasov, Faculty of Wood Engineering, Brașov, România.

${ }^{2}$ Professor at Transilvania University of Brasov, Faculty of Wood Engineering, Brașov, România.

${ }^{3}$ Lecturer at Transilvania University of Brasov, Faculty of Letters, Brașov, România.

•Corresponding Author: lunga@unitbv.ro

Received: 23.02.2016 Accepted: 02.01.2017
} 
Wooden waste, as an important part of the lignocellulosic waste, can be transformed into such renewable combustibles as briquettes, with a clean combustion and inferior noxious emissions as compared to other solid fuels like charcoal (Prasertsan and Sajakulnukit 2006). Transforming wood waste into briquettes aims to improve their characteristics through the increase of density, i.e. one converts the density of around $170-200 \mathrm{~kg} / \mathrm{m}^{3}$ of chips and sawdust in bulk into $900-1000 \mathrm{~kg} / \mathrm{m}^{3}$ in case of briquettes, or into $1100-1200 \mathrm{~kg} / \mathrm{m}^{3}$ in case of pellets. This operation increases the energetic content of biomass per volume unit, respectively the calorific density of these briquettes. Additionally, there is biomass drying and briquettes' storage in dry conditions until they reach the final user, a fact which equally contributes to the improvement of energy efficiency. The use of wood waste contributes to forest preservation as they replace firewood. The wooden briquettes are easier to handle as compared to firewood or small-sized wood waste (dust, sawdust, chips, etc.). The briquetting machines' output is significant, namely more than 200 tons per day. Around 5 million tons of lignocellulosic biomass turned into briquettes and pellets were used in Europe in 2010, for a price of 80-300 Euro/ton, slightly higher for pellets than for briquettes. It should be taken into account that wood waste has no value or their value is very low within a wood processing technological flow. Transforming them into briquettes results in a high value product, easy to handle and transport.

The briquetting pressure of the machines is around $150 \mathrm{MPa}$. Such a high pressure leads to biomass warming (as sawdust, dust and chips) to a temperature of $120^{\circ} \mathrm{C}$, which activates the lignin, becoming sticky and bonding the wooden material, thus obtaining a solid briquette which preserves its condition upon cooling. There are several types of briquetting machines, i.e. hydraulic or pneumatic piston press, worm press, crank arm press and pellet presses (two different models). A complete briquetting plant costs around USD 50000 and it can produce about 1,500 tons/year. The energy consumed for obtaining the briquettes represents $5 \%$ out of the total energy released upon their combustion (Nielsen et al. 2009). Usually, the briquettes are delivered foil-packaged (so that they do not absorb moisture), in packs of no more than $10-15 \mathrm{~kg}$, so that they can be easily handled. Beside the classic combustion into the heating units of individual households, briquettes and pellets may also be used to replace lignite and inferior coal in industry (Lăzăroiu et al. 2009). Briquettes are strong, dense, uniform structure products, superior to raw firewood. Many consumers prefer the wooden briquettes instead of firewood as they have a slow and constant combustion. Briquettes represent a viable alternative for developing countries, while in developed countries they successfully replace pellets and fossil charcoals (Junginger et al. 2008).

There are many studies aiming to increase the calorific content and/or to reduce moisture absorption (Wechsler et al. 2010, Batista et al. 2015), and even to determine the best shape of a briquette in order to optimize combustion efficiency (Mc Dougal et al. 2010). In Europe, there has been an upward trend in the evolution of renewable energy sources (RES), the target being of $20 \%$ in 2020, as it is presented in Figure 1 (EREC 2015, Eurostat 2011, Eurostat 2012).

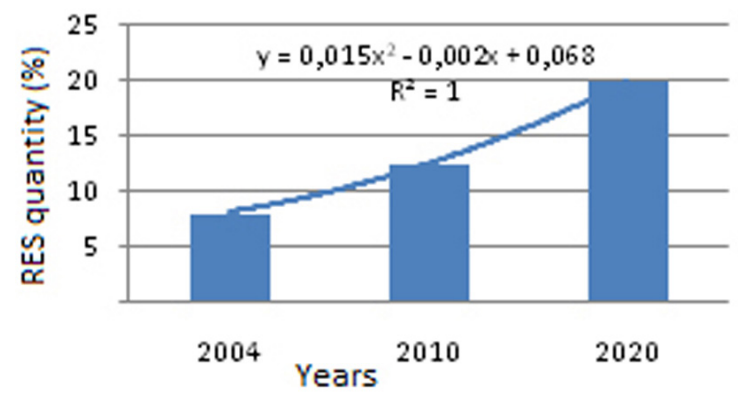

Figure 1. Evolution and target of renewable energy sources (RES) in Europe.

The ligneous biomass resulted in the wood processing industry is one of the most accessible waste resources, readily available in the industrial environment. The most advantageous way to use this renewable resource is to produce briquettes and pellets, thus replacing such fossil resources as pit coal, by a similar calorific value (Boutin et al. 2007, Demirbas 2001). 
Hollow-core briquettes form a special recent category due to some of their distinctive properties. They can be carbonized both on the inside and on the outside, in order to reduce higroscopicity. After ignition in the combustion chamber, in the case of hollow-core briquettes, the flame enters their inner part as a result of the air which gets into the hollow part of the briquette. This is the reason why the flame will cover the briquette completely, and the burning process will be more efficient. This facilitates combustion and increases burning temperature and combustion speed. Consequently, a more complete and a cleaner combustion are obtained, with less smoke, as compared to firewood and charcoal. Hollowcore briquettes are state-of-the-art combustible products which burn faster, constantly release heat and are suitable for domestic and industrial consumers (Mc Dougal et al. 2010, Garcia et al. 2004).

This paper aims to analyse two types of hollow-core briquettes made of coniferous (spruce, Picea abies) and broad-leaved wood waste (oak, Quercus robur) resulted from a timber factory of reconstituted wood panels, from the perspective of physical, mechanical and calorific properties. The comparisons with the classic types of briquettes are made in order to identify the advantages, disadvantages and opportunities of such briquettes on the market.

\section{METHOD AND MATERIALS}

Firstly, the waste resulted from a timber factory with a capacity of around 1 million $\mathrm{m}^{3} / \mathrm{year}$, which produces glued lamellar beams and panels (EN 386:2002, EN 14221:2007), with an efficiency of around $70 \%$, was collected. Then, all wastes (approx. $300000 \mathrm{~m}^{3} /$ year) were grinded and dried, and afterwards they were put into the two briquetting machines, one with a piston press for spruce waste and the second with a screw press for oak waste. Around $200000 \mathrm{t} / \mathrm{year}$ of oak briquettes and around $100000 \mathrm{t} /$ year of spruce briquettes were obtained. Samples from each type of briquette were taken in order to determine the physical, mechanical and calorific characteristics (Figure 2).
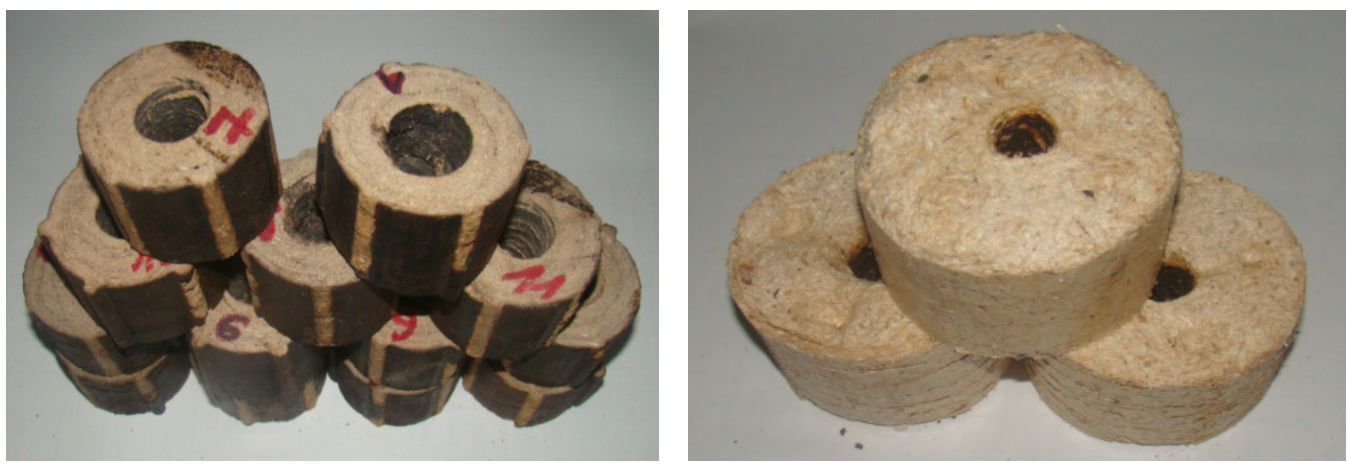

Figure 2. The two types of wooden briquettes.

\section{Dimensions}

The outer and inner diameters as well as the length were considered the main dimensions of these types of briquettes. These dimensions were measured using an electronic calliper, with a 2-decimal places precision. The briquettes' dimensions were measured mainly to determine their density.

\section{Density}

In order to determine the density, pieces of around $50 \mathrm{~mm}$ length were cut from the whole briquette, 
both ends being smooth and perpendicular on the length, in order to precisely measure their length. Pieces were cut from at least 3 different packages. Each piece was marked using figures from 1 to 20 , its mass in grams was determined with a 1-decimal places precision and its dimensions with a 2-decimal places precision. Based on such determinations, the density of each piece of briquette was calculated using the Equation 1:

$$
\rho=\frac{4 \cdot m}{\pi \cdot\left(D^{2}-d^{2}\right) \cdot l}\left(\mathrm{Kg} / \mathrm{m}^{3}\right)
$$

Where:

$\mathrm{D}$ - the briquette's outer diameter, in cm;

$\mathrm{d}$ - the briquette's inner diameter, in $\mathrm{cm}$;

$\mathrm{m}$ - the briquette's mass, in $\mathrm{g}$;

1 - the briquette's length, in $\mathrm{cm}$.

Based on the density of each sample, the average density was determined in the case of each type of briquette, as well as several other related statistical parameters.

\section{Abrasion resistance}

The briquettes' abrasion or technological durability quantifies the briquette's general compactness, and also the wooden particles' reciprocal adherence. In Europe, such determination is standardized according to EN ISO 15210-1 as mechanical durability, but also according to other standards (Kaliyan and Morey 2009, Verma 2009) which cover the use of a rotary crown equipment, inside of which the briquettes are placed to test the friction between them and against the metal parts of the equipment. For the briquettes under analysis a vibrating sorting machine (specific for chipboard laboratories) was used, with the $4 \times 4 \mathrm{~mm}$ sieve. The material extracted from the briquettes consisted of 3 pieces with a total weight of around 100-110 g, and the sorting duration was of 5 minutes. After vibration, the mass of particles falling under the sieve was determined, and based on these masses, the abrasion was determined with the Equation 2:

$$
A=\frac{m_{i}-m_{f}}{m_{i}} \times 100(\%)
$$

Where:

$\mathrm{m}_{\mathrm{i}}$ - the initial mass of the sample under analysis, in $\mathrm{g}$;

$\mathrm{mf}$ - the mass of fine particles falling under the $4 \times 4 \mathrm{~mm}$ sieve, in $\mathrm{g}$.

The arithmetic mean of the 20 determinations was calculated, and then the spreading statistical parameters were determined.

\section{Compression resistance}

The briquettes' compression sets the briquette's compaction, by breaking the briquette after the application of a compression force. The briquette is placed between two flat metal plates, the breaking force is read, and respectively when the force level drops suddenly. Resistance is determined as the ratio between the breaking force and the breaking section area, using the Equation 3:

$$
\sigma=\frac{F}{l \cdot(D-d)}(M P a)
$$

The attention was also focused on the theoretical model of compression force assessment in case of closely stacked briquettes (Figure 3 ) and on the link between the theoretical and practical/experimental aspects. 


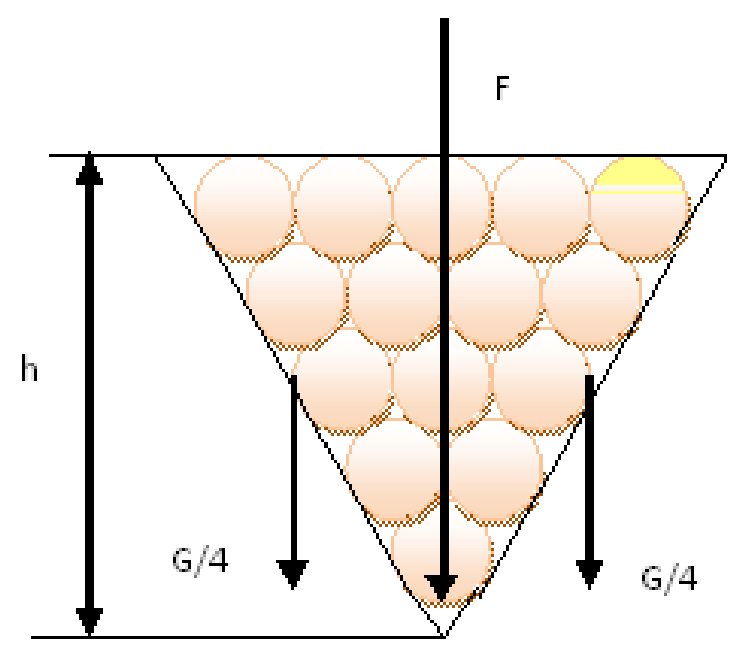

Figure 3. Theoretical model of briquettes subjected to compression.

It may be noted that the briquette placed at the bottom takes the combining weights of all other briquettes, which could break them when the weight $(\mathrm{G})$ exceeds a certain value. The plan model represents an upside down triangle and spatially a pyramid with a square base. Force weighing on the briquettes placed at the bottom would be (Equation 4):

$$
F=m \cdot g \frac{n(n+1)(2 n+1)}{12}(N)
$$

\footnotetext{
Where:

$\mathrm{m}$ - the medium mass of briquettes, in $\mathrm{kg}$; g- the gravitational acceleration $(9,81 \mathrm{~N} / \mathrm{kg})$; $\mathrm{n}$ - the number of rows.
}

\section{Calorific value}

The material was prepared for the purpose of determining the calorific value, i.e. pieces of around 0,6-1,0 g were cut from the whole briquette. From the category of calorific properties, the net and gross calorific values (these values are equal in their moisture content of $0 \%$ ), as well as the calorific density of the analysed briquettes were determined. The methodology used for determining the calorific value with the bomb calorimeter in an oxygenated environment of the type XRY-1C/ Shanghai Changji Geological Instrument Co. LTD, at a pressure of 30 bars, is succinctly presented below, the focus being placed on the impact of the moisture content on the calorific value. Indeed, in order to remove the influence of the moisture content upon the calorific value, some of the samples were dried up to a constant mass into the laboratory oven at a temperature of $103{ }^{\circ} \mathrm{C}$ for 3 hours, then stored into the desiccators until the determination stage. Afterwards, the testing calorimeter was prepared by placing the sample, the nickeline wire and the cotton wire into the bomb. Before the actual determinations, the calorimeter was calibrated with benzoic acid. The machine was then turned on and there was a period of waiting for the elapsing of the three stages: initial, main and final phases. Finally, the high (HCV) and low calorific values (LCV) were recorded. When the moisture content of the sample was $0 \%$, then $\mathrm{HCV}=\mathrm{LCV}=\mathrm{CV}$. The machine's software used the Regnault-Pfaundler formula for determination and calibration, and the relation for $\mathrm{Mc}=0 \%$ was the following (Equation 5): 


$$
C V=\frac{C \cdot\left(T_{f}-T_{i}\right)-\sum q_{i}}{m}(M J / \mathrm{kg})
$$

Where:

$\mathrm{C}$ - the machine`s calibration characteristic;

$\mathrm{T}_{\mathrm{f}}$ - final temperature, in ${ }^{\circ} \mathrm{C}$;

$\mathrm{T}_{\mathrm{i}}$ - initial temperature, in ${ }^{\circ} \mathrm{C}$;

$\mathrm{m}$ - the sample mass, in $\mathrm{g}$;

$\Sigma q i$ - the sum of heat amounts released during the combustion of the nickeline and cotton wire.

The moisture content is the main factor that influences the calorific value therefore the dependence relationship (Krajnc 2015) can be as follows (Equation 6):

$$
N C V_{M c}=\frac{C V \cdot\left(100-M_{c}\right)-2.44 \cdot M_{c}}{100}(M J / k g)
$$

Where:

$\mathrm{CV}$ - the calorific value, for $0 \%$ moisture content, in $\mathrm{MJ} / \mathrm{kg}$;

$\mathrm{M}_{\mathrm{c}}$ - the moisture content, in \%.

The experiment was replicated 20 times for the same type of briquettes and then the statistical parameters of the calorific value were determined.

\section{The calorific density of wooden briquettes.}

This calorific characteristic is determined based on two previously determined characteristics, i.e. calorific value $(\mathrm{CV})$ and briquette density $\left(\rho_{\mathrm{b}}\right)$. The formula is the following (Equation 7):

$$
D_{c}=\rho_{b} \times C_{v}\left(\mathrm{~kJ} / \mathrm{m}^{3}\right)
$$

Twenty determinations were performed and the related statistical parameters were computed.

\section{Specific burn time}

This characteristic is specific for hollow-core briquettes, as the combustion takes place over a larger area, a phenomenon which is triggered by the hollow core area. As the software used for determining the calorific value provides us with the actual burn time as well, we can determine the specific burn time with the following formula (Equation 8):

$$
T_{s}=t / m(\mathrm{~min} / \mathrm{g})
$$

Where:

$\mathrm{t}$ - the burn time into the calorimetric bomb, in minutes;

$\mathrm{m}$ - the mass of the sample placed into the bomb crucible, in $\mathrm{g}$.

Twenty values were used for the determination whereby the mean of values and other statistical 
parameters were obtained.

\section{The speed of energy release}

$\left(\mathrm{S}_{\mathrm{er}}\right)$ expresses the combustion intensity, i.e. how fast the briquettes burn. The calorific value and the specific burn time were used for the determination of speed of energy release, with the following formula (Equation 9):

$$
S_{e r}=\frac{C V}{T_{s}}(\mathrm{~kJ} / \mathrm{min})
$$

Where:

$\mathrm{CV}$ - the calorific value, in $\mathrm{kJ} / \mathrm{kg}$;

$\mathrm{T}_{\mathrm{s}}-$ the specific burn time, in $\mathrm{min} / \mathrm{kg}$.

\section{The ash content}

The material is prepared so as to determine the ash content by chopping the briquettes and sorting the chopped material using a $1 \times 1 \mathrm{~mm}$ mesh sieve. One sample from each type was collected from this material, it was then placed into a high-temperature resistant steel crucible and dried into a laboratory oven at the temperature of $103{ }^{\circ} \mathrm{C}$. Then, all the material was cooled in desiccators, afterwards being weighted with a 3-decimal places precision. Subsequently, the crucible with the sample was placed into a calcinations oven for 1 hour, for complete combustion. Knowing the mass of the empty crucible, the ash content of the wooden briquettes was determined by means of the following formula (Equation 10):

$$
A_{c}=\frac{m_{s i}-m_{c}}{m_{s f}-m_{c}} \times 100(\%)
$$

Where:

$\mathrm{m}_{\mathrm{si}}$ - the mass of the initial sample with the crucible, in $\mathrm{g}$;

$\mathrm{m}_{\mathrm{c}}$ - the mass of the empty crucible, in $\mathrm{g}$;

$\mathrm{m}_{\mathrm{sf}}$ - the mass of the final sample with the crucible, in $\mathrm{g}$.

Ten determinations were performed for each type of briquette and, based on them, the mean and the spreading statistical parameters were determined. A dependency relationship of the net calorific value on the ash content $(A s)$ and moisture content $(M c)$ was also identified, namely (Equation 11):

$$
N C V_{M c}=C V(1-M c-0,1 A s)(M J / k g)
$$

Equation 11 was used to determine the extent to which the calorific value is influenced by the ash content.

\section{RESULTS AND DISCUSSION}

During the experiments, all the dimensional characteristics of the two briquette types were obtained, as shown in Table 1. 
Table 1. The dimensions of the two types of briquettes.

\begin{tabular}{|l|l|l|l|}
\hline \multicolumn{2}{|l|}{ Dimensions } & Spruce Briquettes & Oak briquettes \\
\hline \multirow{2}{*}{ Outer diameter, mm } & Limits & $96,4-97,5$ & $70,4-71,8$ \\
\cline { 2 - 4 } & Mean & 96,8 & 71,6 \\
\hline \multirow{2}{*}{ Inner diameter, mm } & Limits & $20,9-22,1$ & $22,7-29,4$ \\
\cline { 2 - 4 } & Mean & 21,5 & 26,1 \\
\hline \multirow{2}{*}{ Length, mm } & Limits & $18,1-24,8$ & $49,2-59,4$ \\
\cline { 2 - 4 } & Mean & 21,6 & 50,0 \\
\hline
\end{tabular}

The moisture content of briquettes was of about $8 \%$ and this value was maintained, as they were wrapped in foil when delivered and stored. Therefore, their moisture content values were significantly lower than those of firewood (which is over 20-30\%) or unwrapped briquettes. The average density of the spruce briquettes was of $909 \mathrm{~kg} / \mathrm{m}^{3}$ (Table 2), a little lower (by $22 \%$ ) than that of the briquettes made of deciduous hardwood species such as Common oak (Quercus robur), because of different press machines.

Table 2. The main characteristics of hollow-core briquettes.

\begin{tabular}{|l|l|l|}
\hline Features & Spruce hollow-core briquettes & Oak hollow-core briquettes \\
\hline Density, $\mathrm{kg} / \mathrm{m}^{3}$ & 909 & 1,177 \\
\hline Abrasion, \% & 2,306 & 1,58 \\
\hline Compression, $\mathrm{MPa}$ & 1,75 & 1,18 \\
\hline Calorific value, $\mathrm{MJ} / \mathrm{kg}$ & 19,152 & 18,972 \\
\hline Calorific density, $\mathrm{kJ} / \mathrm{m}^{3}$ & 21,06 & 16,11 \\
\hline Specific burn time, $\mathrm{min} / \mathrm{g}$ & 32 & 34 \\
\hline Speed of energy release, $\mathrm{kJ} / \mathrm{min}$ & 0,59 & 0,55 \\
\hline Ash content, \% & 0,42 & 0,85 \\
\hline
\end{tabular}

The values of resistance to breaking by compression of 1,05-2,53 MPa (with a mean of 1,75 for spruce and of 1,18 MPa for oak) show a good compaction of briquettes (i.e. a good crush resistance while they are stacked), considering that around $15-20 \%$ out of the force value is lost on account of the briquette's hollow core (Figure 4).

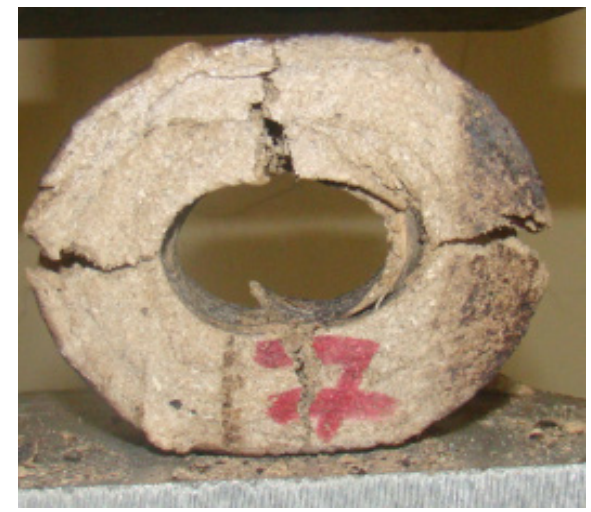

Figure 4. Briquette broken upon compression.

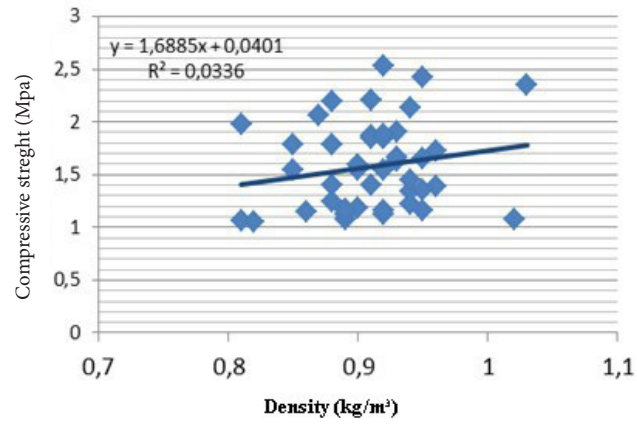

Figure 5. The influence of density on the compressive strength of wooden briquettes.

In this respect, the values of breaking resistance of 1,8-3,1 MPa that had been previously presented regarded cylinder briquettes without a hollow core (Zarringhalam et al. 2011). Note that the hollow- 
core briquettes will break faster, so their storage height must be limited. This fact also affects shipping of briquettes. By using the relationship (7) the storage height had to be reduced from 3,5-4 $\mathrm{m}$ to 2,8-3,2 $\mathrm{m}$ the calculation being done according to the number of briquette rows $(n)$.

Knowing that in the case of solid wood there is a clear interdependence between density and its resistances (Ross 2010), it has also been attempted to find such a correlation in the case of wooden hollow-core briquettes. It was also found that there was a slight correlation between the physical density and their mechanical properties (Stelte et al. 2011). Figure 5 shows this correlation, i.e. the link between the density of the briquettes and the resistance to compression. It revealed that, by increasing the briquettes' density, a slightly greater resistance to compression may be obtained. The great spread of values and a weak Pearson coefficient $\left(\mathrm{R}^{2}\right)$ shows that, in actual fact, a clear and precise correlation of these two parameters cannot be done. This fact is explained by the agglomeration of particles within the briquettes, without adhesive.

The briquettes' resistance to abrasion quantifies their capacity to resist to the friction between them or with other metallic items, both during transportation and afterwards, while being stored by the beneficiary. The experimental values of abrasion resistance below $2,5 \%$ show a good compaction and stability of briquettes. The compressive and abrasion strengths are directly correlated to the grinding degree of chips incorporated within briquettes (Mitchual et al. 2013, Rahman et al. 1989), of 0,5-0,7 for oak and $0,6-1,0 \mathrm{~mm}$ for spruce in our case, averagely determined by sieve sorting and dimension measurements.

The calorific value of the wooden material depends on the wood chemical composition, especially on the lignin content, but also on other wood secondary substances such as resin (Shulga et al. 2008). The calorific values of $18972 \mathrm{MJ} / \mathrm{kg}$ for oak briquettes, respectively of $19152 \mathrm{MJ} / \mathrm{kg}$ for spruce briquettes, show that coniferous briquettes have a slightly higher calorific value (around 5-8\%) than that of the deciduous ones. This value may be explained by the resin content of these wood species, the resin having a very high calorific value, i.e. more than $30 \mathrm{MJ} / \mathrm{kg}$, a value which is close to that of plastic waste (Kers et al. 2013). An example in this respect are the coniferous species with a high content of resin, such as the Scots pine- Pinus sylvestris, its wood having a calorific value higher than that of spruce, i.e. of 19,4 MJ/kg (Pallavi et al. 2013). Obviously, there are also close calorific values of the analysed briquettes as compared to the inferior mineral coal or pit coal type, thus noticing the suitability of briquettes to partly or totally replace coal in heating units.

The calorific density of spruce briquettes is significantly lower than that of oak hardwood, ranging within the general values of classic calorific density of briquettes of $9-24 \mathrm{KJ} / \mathrm{m}^{3}$ (Plištil et al. 2005).

The ash content is higher in the case of oak, but falls within the general values of wood and wooden briquettes of 0,3-0,9\% (Sola and Atis 2012) and it does not depend on the existence of a hollow core. By using Equation 9, a no significant difference of $0,04 \%$ is obtained when the ash content is $0,42 \%$ (in spruce briquettes), or double when an ash content of $0,85 \%$ (in oak briquettes) is used. A significant influence can be obtained when the ash content is more than $5 \%$, i.e. only for wooden bark and cereal straw waste (Plištil et al. 2005, Tabarés et al. 2000).

The differences between the values of the briquettes subjected to analysis and those of the classic ones (without hollow core) are present in case of other characteristics as well, such as the burn time and the speed of energy release. The specific burn times of 32 and $34 \mathrm{~min} / \mathrm{g}$ are lower than those of classic briquettes of $40 \mathrm{~min} / \mathrm{g}$. The speed of energy release has higher values in the case of spruce, namely 0,59 as compared to oak, whose energy release speed is of 0,55; hence, this value is around $15-20 \%$ higher than that of classic briquettes (Demirbas and Demirbas 2004). 
Another deficiency of hollow-core briquettes is related to their storage volume which is slightly above that of classic briquettes, due to their lower effective volume by $4.9 \%$ for spruce and by $13.2 \%$ for oak wood types.

\section{ECONOMICAL COSTS}

The costs of hollow-core briquettes can be considered primarily from the point of view of their price and secondly from the perspective of the annual cost generated for the heating of residential homes/institutions. There are also other important aspects such as the annual demand for fuel, storage space, purchase frequency (if applicable), the total cost of the investment and annual maintenance costs. The consumption in a residential home, per annum and according to building surface, is readily known as follows; home heating 390,4 MJ $/ \mathrm{m}^{2}$.year (about 200 days/year) $46,8 \mathrm{MJ} / \mathrm{m}^{2}$.year for hot water and $216 \mathrm{MJ} / \mathrm{m}^{2}$ year for food cooking and a total of $653,2 \mathrm{MJ} / \mathrm{m}^{2}$ year. On this basis one can proceed to the determination of the annual cost of briquettes, demands and effective costs of briquette use (Table 3) by using a methodology which is similar to the one put forward in another paper.

Table 3. Costs for different types of fuels, used in combustion.

\begin{tabular}{|c|c|c|c|c|c|c|}
\hline No & Features & $\begin{array}{c}\text { Calculation } \\
\text { formula }\end{array}$ & $\begin{array}{l}\text { Hollow-core } \\
\text { briquettes } \\
\text { (oak 10\%) }\end{array}$ & $\begin{array}{c}\text { Classic } \\
\text { briquettes } \\
\text { (oak } 10 \%)\end{array}$ & $\begin{array}{c}\text { Pellets } \\
\text { (oak 10\%) }\end{array}$ & $\begin{array}{l}\text { Methane } \\
\text { gas }\end{array}$ \\
\hline 1 & $\begin{array}{l}\text { Annual energy demand, } \\
\left(\mathrm{MJ} / \text { year } \mathrm{m}^{2}\right)\end{array}$ & - & 653,2 & 653,2 & 653,2 & 653,2 \\
\hline 2 & $\begin{array}{l}\mathrm{NCV}_{\mathrm{Me},}(\mathrm{MJ} / \mathrm{kg}) \\
\left(\mathrm{MJ} / \mathrm{m}^{3}\right)\end{array}$ & $\mathrm{Eq}, 10$ & 16,992 & 16,992 & 16,993 & 35,170 \\
\hline 3 & $\begin{array}{l}\text { Annual fuels demand } \\
\left(\mathrm{kg} / \text { year } \mathrm{m}^{2}\right) \\
\left(\mathrm{m}^{3} / \text { year } \mathrm{m}^{2}\right)\end{array}$ & $1: 2$ & 39,03 & 39,03 & 39,03 & 18,57 \\
\hline 4 & $\begin{array}{l}\text { Unit price of fuel, }(€ / \mathrm{kg}) \text {, } \\
\left(€ / \mathrm{m}^{3}\right)\end{array}$ & - & 0,55 & 0,60 & 1,32 & 1,65 \\
\hline 5 & $\begin{array}{l}\text { Annual price of raw } \\
\text { material, }(€)\end{array}$ & $3 \times 4$ & 21,46 & 23,41 & 51,51 & 30,64 \\
\hline 6 & $\begin{array}{l}\text { Initial investments (per } \\
10 \text { years), }\left(€ / \text { year } \mathrm{m}^{2}\right)\end{array}$ & - & 3,57 & 3,42 & 8,57 & 6,42 \\
\hline 7 & $\begin{array}{l}\text { Maintenance and } \\
\text { amortization for } 10 \\
\text { years, }\left(€ / \text { year } \mathrm{m}^{2}\right)\end{array}$ & - & 2,14 & 2,11 & 3,57 & 4,50 \\
\hline 8 & $\begin{array}{l}\text { Total annual costs, } \\
\left(€ / \text { year } \mathrm{m}^{2}\right)\end{array}$ & $5+6+7$ & 27,17 & 28,94 & 63,65 & 41,56 \\
\hline
\end{tabular}

The starting point would be the calorific value of each fuel type and the general annual energy demand. The calorific value of spruce is brought to a $10 \%$ moisture content, i.e. $16,992 \mathrm{MJ} / \mathrm{kg}$, using Equation 11 and the value of $35,170 \mathrm{MJ} / \mathrm{kg}$ for methane gas is valid for the Eastern area of Europe (Boutin et al. 2007). Then, the other costs are determined successively. To draw a comparison, the same methodology has also been used for regular types of fuel, such as classic briquettes, pellets with a $\mathrm{Mc}=10 \%$ and methane gas. The price of methane gas, of hollow-core briquettes and of pellets, as well as initial investments and a 10 year amortization were also taken into consideration. Note that the lowest annual cost was obtained by using hollow-core briquettes $\left(27,17 € /\right.$ year $\left.\cdot \mathrm{m}^{2}\right)$, immediately followed by briquettes without hollow core $\left(28,94 € /\right.$ year $\left.\cdot \mathrm{m}^{2}\right)$ and finally methane gas and pellets, with 41,56 and $63,65 € /$ year $\cdot \mathrm{m}^{2}$, respectively. 
By customizing the data from Table 3 for a residential house of $180 \mathrm{~m}^{2}$, it will result in an average use of 7,025 t/year in briquettes or pellets with an annual cost of $4890.6 € /$ year in the case of hollowcore briquettes $5209.2 € /$ year in the case of classic briquettes, $11457 € /$ year in the case of pellets and $7480.8 € /$ year in the case of methane gas. For an industrial building (when the cost of food preparation is eliminated) extended over a $1200 \mathrm{~m}^{2}$ area, the annual demand for pellets/briquettes is of $31,5 \mathrm{t}$; with a total price of 117,348 €/year. The maximum price to be paid in the case of pellets is of $160,096 € /$ year, but in this case a complete operational automation and boiler autonomy of about 12-16 hours is provided.

Table 4. SWOT analysis of hollow-core briquettes as compared to classic briquettes.

\begin{tabular}{|l|l|}
\hline Strengths & Weaknesses \\
\hline -Lower price & -Lower compressive strength \\
-Rapid combustion & -High stack of briquettes \\
-Better efficiency of combustion because of the & -Large storage space \\
hollow core & -Lower density \\
-Better costs for household heating & -Higher volume of combustion \\
\hline$\underline{\text { Opportunities }}$ & $\underline{\text { Threats }}$ \\
\hline - The market is weak in this area & - Customers and sellers are sceptical of \\
- The market is looking for new solutions & new trends \\
- Global energy/climate crisis & \\
\hline
\end{tabular}

As it has been noted, the use of hollow-core briquettes has advantages and disadvantages, therefore a SWOT (Strengths-Weaknesses-Opportunities-Threats) analysis is necessary (Table 4) in order to draw a comparison with the classic briquettes.

\section{CONCLUSIONS}

As a main conclusion, the properties of hollow-core briquettes made of coniferous (spruce) and broad-leaved (oak) wood waste are almost similar to those of briquettes without a hollow core. The hollow core of briquettes does not significantly influence the properties of briquettes (except for compressive strength which decreases by $20 \%$ ), but it makes a major contribution to their combustion process, as fire may enter through the hollow core. Consequently, the combustion flame covers a larger area of the briquette, thus increasing the burn temperature and the energy release speed, and reducing the burn time. This is one of the main reasons (apart from economic arguments) why many briquette producers are going to focus, in the near future, on manufacturing these kind of briquettes, thus replacing to a significant extent the classic cylinder briquettes (i.e. without a hollow core).

\section{REFERENCES}

Batista, D.C.; Paez, J.B.; Muñiz G.S.N.; Nisgoski S.; da Silva Oliveira J. T. 2015. Microstructural Aspects of Thermally Modified Eucalyptus Grandis Wood. Maderas- Cienc Tecnol 17(3): 525 - 532. 
Boutin, J.P.; Gervasoni, G.; Help, R.; Seyboth, K.; Lamers, P.; Ratton, M. 2007. Alternative Energy Sources in Transition Countries. The Case of Bio-energy in Ukraine. Environ Eng Manag J 6: 3-11.

Ciubotă-Roşie, C.; Gavrilescu, M.; Macoveanu, M. 2008. Biomass- an Important Renewable Source of Energy in Romania. Environ Eng Manag J 7: 559-568.

Dhillon, R.S.; von Wuelhlisch, G. 2013. Mitigation of Global Warming through Renewable Biomass. Biomass Bioenerg 48: 75-87.

Demirbas, A.; Demirbas, A.S. 2004. Briquetting Properties of Biomass Waste Materials. Energ Source 26(1): 83-91.

Demirbas, A. 2001. Biomass Resource Facilities and Biomass Conversion Processing for Fuels and Chemicals. Energ Convers Manag 42: 1357-1378.

EREC. European Renewable Energy Council. 2015. Renewable energy Technology Roadmap, $20 \%$ by 2020. [On line] [Available from] https://iet.jrc.ec.europa.eu/remea/renewable-energytechnology-roadmap-2020

Eurostat 2011. Forestry in the EU and the World. A Statistical Portrait. [On line] [Available from] [https://ec.europa.eu/eurostat/documents/3217494/5733109/KS-31-11-137-EN.PDF]

Eurostat 2012. Statistics in focus 44/2012. Environment and Energy. Author: Marek ŠTURC, [On line] [Available from] http://ec.europa.eu/eurostat/documents/34334 88/5585312/KS-SF-12-044-EN. PDF/d3dbfde0-5af8-4510-856b-287a6f015665

Krajnc, N. 2015. Wood Fuels Handbook. Food and agriculture organization of the united nations (FAO) Pristina, Croatia [On line] [Available from] https://www.fao.org/3/a-i4441e.pdf

Garcia, A.M.; Barcia, B.M.J.; Diaz, D.M.A.; Hernandez, J.A. 2004. Preparation of Active Carbon from a Comercial Holm-oak Charcoal: Study of Micro-and Meso-porosity. Wood Sci Technol 37: 385-394.

Gavrilescu, D. 2008. Energy from Biomass in Pulp and Paper Mills. Environ Eng Manag J 7: 537-546.

Jehlickova, B.; Morris, R. 2007. Effectiveness of Policy Instruments for Supporting the Use of Waste Wood as a Renewable Energy Resource in the Czech Republic. Energ Policy 35: 577-585.

Junginger, M.; Bolkesjo, T.; Bradley, D.; Dolzan, P.; Faaij, A.; Heinimö, J. 2008. Developments in International Bioenergy Trade. Biomass Bioenerg 32: 717-729

Kaliyan, N.; Morey, R.V. 2009. Factors Affecting Strength and Durability of Densified Biomass Products. Biomass Bioenerg 33: 337-359.

Kers, J.; Kulu, P.; Aruniit, A.; Laurmaa, V.; Križan P.; Šooš, L. 2013. Determination of physical, mechanical and burning characteristics of polymeric waste material briquettes. Estonian Journal of Engineering 19: 307-316.

Kim, S.; Dale, B.E. 2003. Cumulative Energy and Global Warming Impact from the Production of Biomass for Biobased Products. Journal of Industrial Ecology 147-162.

Lăzăroiu, G.; Mihăescu, L.; Prisecaru, T.; Oprea, I.; Pîşă, I.; Negreanu, G. 2009. Combustion of Pitcoal-wood Biomass Briquettes in a Boiler Test Facility. Environ Eng Manag J 7: 595-601.

Lundborg, A. 1998. A Sustainable Forest Fuel System in Sweden. Biomass Bioenerg 15: 399-406. 
Lakó, J.; Hancsók, J.; Yuzhakova, T.; Marton, G.; Utasi, A.; Rédey, A. 2008. Biomass- a Source of Chemicals and Energy for Sustainable Development. Environ Eng Manag J 7: 499-509.

Mitchual, S.J.; Frimpong-Mensah, K.; Darkwa, N.A. 2013. Effect of Species, Particle Size and Compacting Pressure on Relaxed Density and Compressive Strength of Fuel Briquettes. International Journal of Energy and Environmental Engineering. 4: 30-36.

Mc Dougal, O.; Eidemiller, S.; Weires, N. 2010. Biomass Briquettes: turning Waste into Energy. Biomass Magazine, [On line] [Available from] http://biomassmagazine.com/articles/5148/biomassbriquettes-turning-waste-into-energy.

Nielsen, N.P.K.; Gardner, D.J.; Poulsen, T.; Felby, C. 2009. Importance of Temperature, Moisture Content and Species for the Conversion Process of Wood Residues into Fuel Pellets. Wood Fiber Sci 41: 414-425.

Plištil, D.; Brožek, M.; Malaták, J.; Roy, A.; Hutla, P. 2005. Mechanical Characteristics of Standard Fuel Briquettes on Biomass Basis. Res Agr Eng 51: 66-72. [On line] [Available from] https:// agriculturejournals.cz/publicFiles/57241.pdf

Prasertsan, S.; Sajakulnukit, B. 2006. Biomass and Bioenergy in Thailand: Potential, Opportunity and Barriers. Renew Energ 31: 599-610.

Tabarés, J.L.M.; Ortiz, L.; Granada, E.; Viar, F.P. 2000. Feasibility Study of Energy Use for Densificated Lignocellulosic Material (briquettes). Fuel 79: 1229-1237.

Pallavi, H.V.; Srikantaswamy, S.; Kiran, B.M.; Vyshnavi, D.R.; Ashwin, C.A. 2013. Briquetting Agricultural Waste as an Energy Source. Journal of Environmental Science, Computer Science and Engineering and Technology 2: 160-172.

Rahman, A.N.E.; Masood, M.A.; Prasad, C.S.N.; Venkatesham, M. 1989. Influence of Size and Shape on the Strength of Briquettes. Fuel Process Technol 23: 185-195.

Ross, R. 2010. Wood Handbook. Wood as an engineering material. Centennial Edition. USDA Forest Service Forest Products Laboratory, USA, [On line] [Available from] https://www.woodweb. com/Resources/wood_eng_handbook/wood_handbook_fpl_2010.pdf.

Thomas, S.C.; Malczewski, G. 2007. Wood Carbon Content of Tree Species in Eastern China: Interspecific Variability and the Importance of the Volatile Fraction. J Environ Manag 85: 659-662.

Stelte, W.; Holm, J.K.; Sanadi, A.R.; Barsberg, S.; Ahrenfeldt, J.; Henriksen, U.B. 2011. A study of bonding and failure mechanisms in fuel pellets from different biomass resources. Biomass Bioenerg 35: 910-918.

Shulga, G.; Betkers, T.; Brovkina, J.; Aniskevicha, O.; Ozolinš, J. 2008. Relationship between Composition of the Lignin-based Interpolymer Complex and its Structuring Ability. Environ Eng Manag J 7: 397-400.

Sola, O.C.; Atis, C.D. 2012. The Effects of Pyrite Ash on the Compressive Strength Properties of Briquettes. KSCE Journal of Civil Engineering 16: 1225-1229.

Verma, V.K.; Bram, S.; de Ruyck, J. 2009. Small Scale Biomass Systems: Standards, Quality Labeling and Market Driving Factors - An EU Outlook. Biomass Bioenerg 33: 1393-1402.

Wechsler, M.; Shulenberger, A.; Wall, C.; Braig, J. 2010. Torrefaction Method and Apparatus. Renewable Fuel Technologies. San Jose, CA, USA.

Zarringhalam, M.A.; Gholipour, Z.N.; Dorosti, S.; Vaez, M. 2011. Physical properties of solid 
fuel briquettes from bituminous coal waste and biomass. Journal of Coal Science and Engineering (China) 17: 434-438. 